УДК 633.35:579.83./88(477)

(C) 2016

Пилипенко В. С., аспірант

(науковий керівник - доктор сільськогосподарських наук С. М. Каленська)

Національний університет біоресурсів і природокористування України

\title{
ФОРМУВАННЯ ТА СИМБІОТИЧНА АКТИВНІСТЬ БУЛЬБОЧКОВИХ БАКТЕРІЙ РОСЛИН ГОРОХУ ВУСАТОГО В ЛІСОСТЕПУ УКРАЇНИ
}

\section{Рецензент - кандидат сільськогосподарських наук Н. О. Ящук}

Наведені основні результати дослідження, проведеного в північній частині Правобережного Лісостепу України протягом 2014-2016 рр. на чорноземі типовому. Встановлено, щзо сортові особливості культури, передпосівна обробка насіння «Ризогуміном» та удобрення мали позитивний вплив на формування кількості $і$ маси бульбочок у рослин гороху. Найбільш сприятливі умови для формування симбіотичного апарату створюються за поєднання посівної інокуляиї насіння із внесенням мінеральних добрив у варіанті $K_{1}+N_{10} P_{10 \text { BвCH13-19 }}+N_{10} P_{10 \text { BBCH55-59 }}+N_{10} P_{10 \text { BBCH61-65. }}$ На фоні внесення мінеральних добрив $N_{30} P_{90} K_{90}$ посилюється формування та продуктивність симбіотичного апарату рослин гороху. Вказаний рівень мінерального живлення є ефективним $і$ за сівби насінням, яке не підлягало інокуляції. Внесення високих рівнів мінерального азоту негативно впливає на симбіотичний зв'язок між рослинами гороху $i$ бульбочковими бактеріями.

Ключові слова: сорт, горох вусатий, бульбочкові бактерії, інокулячія насіння, удобрення.

Постановка проблеми. Проблемою світового землеробства як у минулому, так і на початку нинішнього сторіччя є проблема виробництва білка. Тому пошук джерел високобілкових рослинних ресурсів $\epsilon$ актуальним для всього людства, і у тому числі й для населення України. Від іiї вирішення залежить стан здоров'я, тривалість i рівень життя людей та продуктивність тваринництва. У вирішенні важливої проблеми збільшення виробництва рослинного білка особливе місце належить зернобобовим культурам, зокрема гороху.

Аналіз останніх досліджень та публікацій, у яких започатковано розв'язання проблеми. Одним із найбільш об'єктивних критеріїв оптимального застосування засобів хімізації в технологіях вирощування, на думку багатьох дослідників, є мікробіологічне тестування. Водночас визначальними критеріями оцінки виступали показники чисельності мікроорганізмів та активності ферментів [2]. Однак з огляду на тісну взаємодію окремих видів мікроорганізмів з культурними рослинами та можливість утворення ними тісних рослинно-бактеріальних асоціацій у грунті, на думку дослідників Інституту сільськогосподарської мікробіології НААН тільки ризосферні (кореневі мікроорганізми) можуть відображати реакцію системи на певний чинник, найбільш наближену до реакції самої рослини [10]. Подібна проблематика висвітлюється в роботах багатьох авторів як кінця минулого століття, так і в більш сучасних матеріалах зарубіжних і вітчизняних науковців $[8,5]$.

3-поміж багатьох переваг гороху посівного його важливою особливістю $є$ здатність рослин до симбіозу з бульбочковими бактеріями. Крім того, завдяки симбіотичній азотфіксації вони відіграють важливу роль у підтриманні позитивного балансу азоту в землеробстві $[6,7,2]$. Раціональне використання людиною симбіотичної азотфіксації дає змогу підвищувати родючість грунтів та отримувати стабільно високі врожаї гороху посівного, не піддаючи ризику забруднення довкілля.

На даний час залишається відкритим питання щодо доцільного застосування азотних добрив за вирощування зернобобових культур. Існує думка, що отримання високого врожаю гороху посівного можливе шляхом забезпечення мінеральним азотом незалежно від його впливу на симбіотичний апарат, адже екологічні умови вирощування часто не співпадають 3 біологічними вимогами рослин, внаслідок чого симбіотична фіксація азоту з повітря послаблюється [1].

Відомо, що підвищення продуктивності зернобобових культур, у тому числі гороху, визначається багатьма факторами, серед яких першочергова роль належить азоту. Для того, щоб отримувати високі врожаї сільськогосподарських культур, необхідно постійно дбати про поповнення запасів азоту в грунті за рахунок азотфіксуючих бактерій $[9,11]$. Виходячи з недостатнього вивчення питання щодо впливу мінерального удобрення на формування та симбіотичну активність бульбочкових бактерій, була встановлена актуальність даної роботи. 


\section{СТОРІНКА МОЛОДОГО ВЧЕНОГО}

Мета дослідження. Одним із напрямів наших досліджень $є$ встановити особливості формування симбіотичного апарату бульбочкових бактерій рослин гороху вусатого морфотипу в Лісостепу України залежно від удобрення та інокуляції насіння біопрепаратом «Ризогумін».

Матеріали i методика дослідження. Об'єктом дослідження є процеси росту та розвитку і формування симбіотичної активності бульбочкових бактерій залежно від інокуляції насіння та удобрення.

Предмет дослідження: сорти гороху вусатого морфотипу - Царевич і Девіз, інокуляція насіння, удобрення та урожайність гороху в північній частині Правобережного Лісостепу України.

Дослідження проводилися у 2014-2016 роках у стаціонарному досліді кафедри рослинництва у ВП Національного університету біоресурсів і природокористування України «Агрономічна дослідна станція» (с. Пшеничне, Васильківський район, Київська область).

Для досягнення поставленої мети було закладено польовий трифакторний дослід (табл. 1).

Грунт дослідної ділянки - чорнозем типовий малогумусний, за гранулометричним складом грубопилувато-середньосуглинковий зі вмістом гумусу в орному шарі грунту 4,53-4,38\%, $\mathrm{pH}$ сольової витяжки - 6,8-7,3.
Площа посівної ділянки $-30 \mathrm{~m}^{2}$, облікової $-25 \mathrm{~m}^{2}$.

Повторність досліду чотириразова, розміщення варіантів послідовне $[3,4]$.

Основне удобрення вносили під передпосівний обробіток грунту.

Норма висіву становила 1,2 млн насінин на 1 гектар. У день сівби проводили бактеризацію суспензійним біопрепаратом «Ризогуміном», що містить живу культуру бульбочкових бактерій Rhizobiumleguminosarum 31 (титр бульбочкових бактерій становить $2,0 \times 10^{9}$ клітин у 1 г препарату).

Суспензійний біопрепарат у день обробки насіння в нормі 900 г на 1 т насіння розводили в 810 л води ретельно перемішували і відразу обробляли насіння гороху розчином.

Дослідження проводили на рослинах гороху в стадіях росту і розвитку рослин: ВВСН 13-19 (3 листа або вусики (з прилистками) розвинені), ВВСН 55-59 (перші відокремлені квіткові бруньки видно за листям, але квіти все ще закриті), ВВCH 61-65 (початок цвітіння: 10-50 \% квітів відкриті) [12].

Гідротермічні умови вегетаційного періоду гороху у роки проведення досліджень були неоднорідними, що дало змогу всебічно встановити ефективність досліджуваних чинників.

\section{1. Схема польового досліду}

\begin{tabular}{|c|c|c|}
\hline $\begin{array}{c}\text { Фактор C: } \\
\text { сорт }\end{array}$ & $\begin{array}{l}\text { Фактор Д: } \\
\text { удобрення }\end{array}$ & $\begin{array}{c}\text { Фактор I: } \\
\text { інокуляція насіння }\end{array}$ \\
\hline & $Д_{1}-$ Контроль (без добрив $\left.-K_{1}\right)$ & \\
\hline $\mathrm{C}_{1}-$ Девіз & Д $_{2}-\mathrm{N}_{30} \mathrm{P}_{60} \mathrm{~K}_{60}\left(\mathrm{~K}_{2}\right)$ & $\mathrm{I}_{1}-$ Без інокуляції \\
\hline \multirow[t]{10}{*}{$\mathrm{C}_{2}-$ Царевич } & Д $_{3}-\mathrm{N}_{60} \mathrm{P}_{60} \mathrm{~K}_{60}$ & $\mathrm{I}_{2}-$ Інокуляція \\
\hline & $Д_{4}-\mathrm{N}_{30} \mathrm{P}_{90} \mathrm{~K}_{60}$ & \\
\hline & $Д_{5}-\mathrm{N}_{90} \mathrm{P}_{90} \mathrm{~K}_{60}$ & \\
\hline & Д $_{6}-\mathrm{N}_{30} \mathrm{P}_{90} \mathrm{~K}_{90}$ & \\
\hline & Д $_{7}-\mathrm{K}_{1}+\mathrm{N}_{10 \text { ВBCH13-19 }}+\mathrm{N}_{10 \text { ВBCH 55-59 }}+\mathrm{N}_{10 \text { ВBCH61-65 }}$ & \\
\hline & $Д_{8}-\mathrm{K}_{1}+\mathrm{P}_{10 \text { вВCH13-19 }}+\mathrm{P}_{10 \text { вBCH55-59 }}+\mathrm{P}_{10 \text { ВВСн61-65 }}$ & \\
\hline & $\begin{array}{c}Д_{9}-\mathrm{K}_{1}+\mathrm{N}_{10} \mathrm{P}_{10 \text { BBCH13-19}}+\mathrm{N}_{10} \mathrm{P}_{10 \text { BBCH55-59 }}+ \\
+\mathrm{N}_{10} \mathrm{P}_{10 \text { BBCH61-65 }}\end{array}$ & \\
\hline & $Д_{10}-\mathrm{K}_{2}+\mathrm{N}_{10 \text { ввСH13-19 }}+\mathrm{N}_{10 \text { вВСH 55-59 }}+\mathrm{N}_{10 \text { ВBCH61-65 }}$ & \\
\hline & Д $_{11}-\mathrm{K}_{2}+\mathrm{P}_{10 \text { ВвСH13-19 }}+\mathrm{P}_{10 \text { BВCH55-59 }}+\mathrm{P}_{10 \text { ВBCH61-65 }}$ & \\
\hline & $\begin{array}{c}\text { Д }_{12}-\mathrm{K}_{2}+\mathrm{N}_{10} \mathrm{P}_{10 \text { вBCH13-19 }}+\mathrm{N}_{10} \mathrm{P}_{10 \text { вBCH55-59 }}+ \\
+\mathrm{N}_{10} \mathrm{P}_{10 \text { BBCH61-65 }}\end{array}$ & \\
\hline
\end{tabular}


Попередником гороху посівного в сівозміні $є$ ріпак озимий. Сівбу проводили за температури грунту на глибині заробки насіння $3-5^{\circ} \mathrm{C}$ сівалкою «Great Plains» 3 шириною міжрядь $18 \mathrm{~cm}$ та глибиною заробки насіння 4-6 см. Для захисту посівів від бур'янів застосовували післясходовий гербіцид «Пульсар» у нормі 1,2 л/га.

Лабораторні дослідження проводили у навчально-науковій лабораторії «Аналітичних досліджень в рослинництві» кафедри рослинництва Національного університету біоресурсів і природокористування України.

Результати дослідження. Інокуляція насіння «Ризогуміном» мала позитивний вплив на формування симбіотичного апарату гороху посівного вусатого морфотипу. Від застосування даного технологічного заходу, удобрення та сортових особливостей культури, кількість і маса бульбочок мг/100 рослин варіювала у варіантах дослідження (табл. 2-3).

Динаміку симбіотичного апарату рослин гороху проводили на стадіях ВВСН 13-19; 55-59; 61-65 та було відмічено зростання симбіотичної активності бульбочок до ВВСН 61-65.

Умови формування симбіотичного апарату гороху сорту Девіз були найбільш сприятливими за сівби інокульованим насінням на фоні мінерального удобрення $\mathrm{N}_{30} \mathrm{P}_{90} \mathrm{~K}_{90}$ та позакореневого підживлення $\mathrm{K}_{1}+\mathrm{N}_{10} \mathrm{P}_{10}$ ввсн13-19 $+\mathrm{N}_{10} \mathrm{P}_{10}$ ввсн55-59 + $\mathrm{N}_{10} \mathrm{P}_{10}$ ввсн61-65. У цих варіантах значення кількості та маси бульбочок були найвищими та варіювали від 52,4 до 54,8 шт./рослину та від 26,2 до 27,4 г/100 рослин (табл. 2).

Внесення підвищених доз мінерального азоту до сівби негативно впливало на розміри симбіотичного апарату. Це було зафіксовано у варіанті $\mathrm{N}_{90} \mathrm{P}_{90} \mathrm{~K}_{60}$, де кількість та маса бульбочок були на рівні контролю або навіть менше, тобто спостерігали пригнічення симбіотичного апарату.

Проведення підживлення азотним добривом

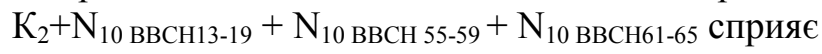
утворенню бульбочок на корені рослин гороху, але не так інтенсивно як у варіанті


Проведення підживлення фосфорним добривом $\mathrm{P}_{10 \text { ввсн13-19 }}+\mathrm{P}_{10 \text { ввсн55-59 }}+\mathrm{P}_{10 \text { ввСн61-65 було вста- }}$ новлено, що збільшилась кількість бульбочок порівняно 3 контролем і варіантом $\mathrm{K}_{2}+\mathrm{N}_{10 \text { ввсн13-19 }}$

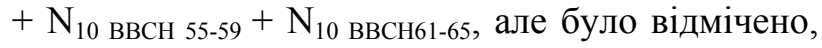
що дані бульбочки були менші за розмірами та масою.

2. Симбіотична активність бульбочкових бактерій рослин гороху сорту Девіз залежно від удобрення, позакореневого підживлення та інокуляції насіння (середнє за 2014-2016 рр.)

\begin{tabular}{|c|c|c|c|c|c|c|c|c|c|c|c|c|}
\hline \multirow{5}{*}{ 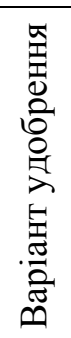 } & \multicolumn{12}{|c|}{ Стадії росту та розвитку рослин } \\
\hline & \multicolumn{4}{|c|}{$\mathrm{BBCH} 13-19$} & \multicolumn{4}{|c|}{ BBCH 55-59 } & \multicolumn{4}{|c|}{ BBCH 61-65 } \\
\hline & \multicolumn{12}{|c|}{ Передпосівна обробка насіння «Ризогуміном» } \\
\hline & $\sigma / i^{1}$ & $i^{2}$ & $\bar{\sigma} / \mathrm{i}$ & $\mathrm{i}$ & $6 / \mathrm{i}$ & $\mathrm{i}$ & $6 / i$ & $\mathrm{i}$ & $\sigma / i$ & $\mathrm{i}$ & $\sigma / i$ & $\mathrm{i}$ \\
\hline & \multicolumn{2}{|c|}{$\begin{array}{c}\text { Кількість } \\
\text { бульбочок, } \\
\text { шт./рослину }\end{array}$} & \multicolumn{2}{|c|}{$\begin{array}{l}\text { Маса } \\
\text { ульбочок, } \\
100 \text { рослин }\end{array}$} & \multicolumn{2}{|c|}{$\begin{array}{c}\text { Кількість } \\
\text { бульбочок, } \\
\text { шт./рослину }\end{array}$} & \multicolumn{2}{|c|}{$\begin{array}{c}\text { Маса } \\
\text { бульбочок, } \\
\text { г/100 рослин }\end{array}$} & \multicolumn{2}{|c|}{$\begin{array}{c}\text { Кількість } \\
\text { бульбочок, } \\
\text { шт./рослину }\end{array}$} & \multicolumn{2}{|c|}{$\begin{array}{c}\text { Маса } \\
\text { бульбочок, } \\
\text { г/100 рослин }\end{array}$} \\
\hline$Д_{1}$ & 7,1 & 13,2 & 3,6 & 6,6 & 18,1 & 25,5 & 9,1 & 12,8 & 22,2 & 33,9 & 11,1 & 17,0 \\
\hline Д $_{2}$ & 10,3 & 17,4 & 5,2 & 8,7 & 23,4 & 36,1 & 11,7 & 18,1 & 39,1 & 50,6 & 19,6 & 25,3 \\
\hline Д $_{3}$ & 5,2 & 10,5 & 2,6 & 5,3 & 17,3 & 27,3 & 8,7 & 13,7 & 24,3 & 34,3 & 12,2 & 17,2 \\
\hline $\mathrm{Z}_{4}$ & 7,2 & 23,1 & 3,6 & 11,6 & 27,6 & 38,1 & 13,8 & 19,1 & 41,5 & 51,1 & 20,8 & 25,6 \\
\hline Д $_{5}$ & 3,0 & 13,1 & 1,5 & 6,6 & 16,1 & 23,3 & 8,1 & 11,7 & 23,1 & 32,8 & 11,6 & 16,4 \\
\hline Д $_{6}$ & 11,6 & 18 & 5,8 & 9,0 & 27,7 & 39,5 & 13,9 & 19,8 & 42,8 & 52,4 & 21,4 & 26,2 \\
\hline Д $_{7}$ & 7,5 & 17,3 & 3,8 & 8,7 & 27,4 & 30,6 & 13,7 & 15,3 & 31,4 & 41,2 & 15,7 & 20,6 \\
\hline Д $_{8}$ & 8,5 & 17,2 & 4,3 & 8,6 & 26,8 & 31,1 & 13,4 & 15,6 & 34,2 & 45,1 & 17,1 & 22,6 \\
\hline Д9 $_{9}$ & 7,5 & 18,5 & 3,8 & 9,3 & 21,2 & 32,4 & 10,6 & 16,2 & 37,1 & 54,8 & 18,6 & 27,4 \\
\hline$Д_{10}$ & 11,1 & 17,4 & 5,6 & 8,7 & 20,4 & 27,5 & 10,2 & 13,8 & 30,9 & 39,4 & 15,5 & 19,7 \\
\hline $\boldsymbol{Д}_{11}$ & 10,2 & 18,3 & 5,1 & 9,2 & 20,3 & 33,8 & 10,2 & 16,9 & 36,5 & 44,2 & 18,3 & 22,1 \\
\hline$Д_{12}$ & 11,3 & 17,1 & 5,7 & 8,6 & 25,1 & 35,3 & 12,6 & 17,7 & 39,2 & 46,3 & 19,6 & 23,2 \\
\hline \multicolumn{9}{|c|}{$\begin{array}{c}\text { НIP } 05 \text { для фактора «удобрення» } \\
\text { НІР }_{05} \text { для фактора «інокулячія насіння» }\end{array}$} & & & \multicolumn{2}{|c|}{$\begin{array}{l}1,3 \\
0,6\end{array}$} \\
\hline
\end{tabular}

Примітки: ${ }^{1}$ - без інокуляції насіння; ${ }^{2}$ - інокульоване насіння. 
3. Симбіотична активність бульбочкових бактерій рослин гороху сорту Царевич залежно від удобрення, позакореневого підживлення та інокуляції насіння (середнє за 2014-2016 рр.)

\begin{tabular}{|c|c|c|c|c|c|c|c|c|c|c|c|c|}
\hline \multirow{5}{*}{ 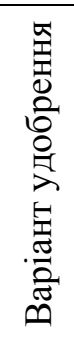 } & \multicolumn{12}{|c|}{ Стадії росту та розвитку рослин } \\
\hline & \multicolumn{4}{|c|}{ BBCH 13-19 } & \multicolumn{4}{|c|}{ BBCH 55-59 } & \multicolumn{4}{|c|}{ BBCH 61-65 } \\
\hline & \multicolumn{12}{|c|}{ Передпосівна обробка насіння «Ризогуміном» } \\
\hline & $6 / i^{1}$ & $i^{2}$ & $\sigma / \mathrm{i}$ & $\mathrm{i}$ & $6 / i$ & $\mathrm{i}$ & $6 / \mathrm{i}$ & $\mathrm{i}$ & $6 / \mathrm{i}$ & $\mathrm{i}$ & $\sigma / i$ & $\mathrm{i}$ \\
\hline & \multicolumn{2}{|c|}{$\begin{array}{c}\text { Кількість } \\
\text { бульбочок, } \\
\text { шт./рослину }\end{array}$} & \multicolumn{2}{|c|}{$\begin{array}{c}\text { Маса } \\
\text { бульбочок, } \\
\text { г/100 рослин }\end{array}$} & \multicolumn{2}{|c|}{$\begin{array}{c}\text { Кількість } \\
\text { бульбочок, } \\
\text { шт./рослину }\end{array}$} & \multicolumn{2}{|c|}{$\begin{array}{c}\text { Маса } \\
\text { бульбочок, } \\
\text { г/100 рослин }\end{array}$} & \multicolumn{2}{|c|}{$\begin{array}{c}\text { Кількість } \\
\text { бульбочок, } \\
\text { шт./рослину }\end{array}$} & \multicolumn{2}{|c|}{$\begin{array}{c}\text { Маса } \\
\text { бульбочок, } \\
\text { г/100 рослин }\end{array}$} \\
\hline$Д_{1}$ & 8,6 & 14,1 & 4,3 & 7,1 & 19,5 & 27,2 & 9,8 & 13,6 & 25,2 & 34,9 & 12,6 & 17,5 \\
\hline$Д_{2}$ & 11,2 & 18,6 & 5,6 & 9,3 & 24,3 & 38,6 & 12,2 & 19,3 & 42,6 & 53,1 & 21,3 & 26,6 \\
\hline$Д_{3}$ & 6,4 & 11,2 & 3,2 & 5,6 & 18,8 & 29,4 & 9,4 & 14,7 & 27,9 & 37,4 & 14,0 & 18,7 \\
\hline$Д_{4}$ & 8,7 & 13,6 & 4,4 & 6,8 & 28,5 & 40,7 & 14,3 & 20,4 & 44,1 & 54,7 & 22,1 & 27,4 \\
\hline Д $_{5}$ & 4,2 & 14,3 & 2,1 & 7,2 & 17,2 & 25,4 & 8,6 & 12,7 & 26,4 & 35,8 & 13,2 & 17,9 \\
\hline$Д_{6}$ & 12,5 & 19,6 & 6,3 & 9,8 & 28,6 & 41,8 & 14,3 & 20,9 & 45,7 & 55,2 & 22,9 & 27,6 \\
\hline$Д_{7}$ & 8,8 & 18,8 & 4,4 & 9,4 & 28,8 & 32,5 & 14,4 & 16,3 & 34,5 & 44,4 & 17,3 & 22,2 \\
\hline$Д_{8}$ & 9,5 & 18,3 & 4,8 & 9,2 & 27,5 & 33,2 & 13,8 & 16,6 & 37,2 & 48,8 & 18,6 & 24,4 \\
\hline Д9 $_{9}$ & 8,7 & 19,5 & 4,4 & 9,8 & 22,3 & 34,7 & 11,2 & 17,4 & 40,9 & 57 & 20,5 & 28,5 \\
\hline$Д_{10}$ & 12,7 & 18,9 & 6,4 & 9,5 & 21,6 & 29,2 & 10,8 & 14,6 & 33,2 & 42,2 & 16,6 & 21,1 \\
\hline$Д_{11}$ & 11,5 & 19,3 & 5,8 & 9,7 & 21,1 & 35,6 & 10,6 & 17,8 & 39,5 & 47,5 & 19,8 & 23,8 \\
\hline$Д_{12}$ & 12,9 & 18,8 & 6,5 & 9,4 & 26,7 & 37,2 & 13,4 & 18,6 & 42,7 & 49,7 & 21,4 & 24,9 \\
\hline \multicolumn{9}{|c|}{$\begin{array}{c}\text { HIP }_{05} \text { для фактора «удобрення» } \\
\text { HІР }_{05} \text { для фактора «інокуляція насіння» }\end{array}$} & \multicolumn{2}{|c|}{$\begin{array}{l}1,2 \\
0,6\end{array}$} & \multicolumn{2}{|c|}{$\begin{array}{l}1,3 \\
0,6\end{array}$} \\
\hline
\end{tabular}

Примітки: ${ }^{1}$ - без інокуляції насіння; ${ }^{2}$ - інокульоване насіння.

Встановлено, що сортові особливості також мали вплив на формування та симбіотичну активність бульбочкових бактерій. Провівши порівняльний аналіз досліджуваних сортів маємо зауважити, що сорт Царевич формував більшу кількість бульбочок та відповідно більшу масу (табл. 3).

Симбіотична активність бульбочок рослин гороху сорту Царевич була найбільш сприятливою за сівби інокульованим насінням на фоні мінерального удобрення $\mathrm{N}_{30} \mathrm{P}_{90} \mathrm{~K}_{90}$ i $\mathrm{K}_{1}+\mathrm{N}_{10} \mathrm{P}_{10 \text { ввсн13-19 }}+$


бульбочок були найвищими у даних варіантах та становили 55,2-57,0 шт./рослину та 27,6-28,5 г/100 рослин. Підвищені дози азоту мали негативний вплив на кількість та масу бульбочок. Потрібно зауважити, що внесення добрив під основний обробіток грунту має позитивний вплив на утворення бульбочок та на їх величину. Але не всі дози добрив сприяють симбіотичній активності бульбочкових бактерій рослин гороху, про що свідчать отримані дані. Так, за внесення підвищених доз азоту 90 кг/га д.р. спостерігали знищення симбіотичної активності, яка була навіть нижчою за контроль. На коренях рослин гороху у варіанта $\mathrm{N}_{90} \mathrm{P}_{90} \mathrm{~K}_{60}$ було зафіксовано найменшу кількість бульбочок на стадії ВВСН 13-19 - 4,2 шт./рослину. Дані бульбочки за роз- мірами і вагою були менші за контроль.

Протягом наступних стадій росту та розвитку, на яких проводились спостереження, було відмічено аналогічну тенденцію.

Симбіотична активність бульбочок рослин гороху сорту Царевич була найбільш сприятливою за сівби інокульованим насінням на фоні мінерального удобрення $\mathrm{N}_{30} \mathrm{P}_{90} \mathrm{~K}_{90}$ i $\mathrm{K}_{1}+\mathrm{N}_{10} \mathrm{P}_{10 \text { ввсн13-19 }}+$

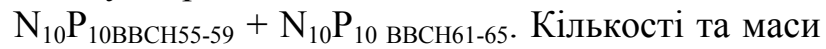
бульбочок були найвищими у даних варіантах та становили 55,2-57,0 шт./рослину та 27,6-28,5 г/100 рослин. Підвищені дози азоту мали негативний вплив на кількість та масу бульбочок.

Висновок. Найбільш сприятливі умови для формування симбіотичного апарату створюються за поєднання посівної інокуляції насіння із внесенням мінеральних добрив у варіанті $\mathrm{K}_{1}+\mathrm{N}_{10} \mathrm{P}_{10 \text { BвCH13-19 }}+\mathrm{N}_{10} \mathrm{P}_{10 \text { вBCH55-59 }}+\mathrm{N}_{10} \mathrm{P}_{10 \text { ввCH61-65. }}$. Внесення мінерального азоту негативно впливає на симбіотичний зв'язок між рослинами гороху i бульбочковими бактеріями. На фоні внесення мінеральних добрив $\mathrm{N}_{30} \mathrm{P}_{90} \mathrm{~K}_{90}$ посилюється формування та продуктивність симбіотичного апарату рослин гороху. Вказаний рівень мінерального живлення є ефективним і за сівби насінням, яке не підлягало інокуляції. 


\section{БІБЛІОГРАФІЯ}

1. Біологічний азот : монографія / [Патика В. П., Коць С. Я., Волкогон В. В. та ін.] ; за ред. В. П. Патики. - К. : Світ, 2003. - 424 с.

2. Волкогон В. В. Мікробіологічні аспекти оптимізації азотного удобрення сільськогосподарських культур : монографія / В. В. Волкогон. - К. : Аграрна наука, 2007. - 144 с.

3. Дослідна справа в агрономії. Книга друга. Статистична обробка результатів агрономічних досліджень : навчальний посібник / [Рожков А. О., Каленська С. М., Пузік Л. М. та ін.]. - Х. : Майдан, 2016. -298 с.

4. Дослідна справа в агрономії : навч. посібник : у 2 кн. - Книга 1. Теоретичні аспекти дослідної справи / [Рожков А. О., Пузік В. К., Каленська С. М. та ін.] ; за ред. А. О. Рожкова. - Х. : Майдан, 2016. - $316 \mathrm{c}$.

5. Використання біологічно-активних препаратів на основі нанорозмірних частинок металів в технології вирощування сої / [Каленська С. М., Новицька Н. В., Андрієць Д. В., Холодченко Р. М.] // Вісник Харківського НАУ. - Серія «Біологія». 2010. - Ч.2. - C. 24-32.

6. Каленська С. М. Вплив елементів технології вирощування на формування структурних елементів фітоценозу нуту / С. М. Каленська, I. T. Нетупська // Науковий вісник НУБіП України. $-2011 .-$ С. 162.

7. Каленська С. М. Формування врожаю нуту під впливом елементів технології вирощування / С. М. Каленська, І. Т. Нетупська, Н. В. Новицька // Вісник Полтавської державної аграрної академії. 2012. - №2. - C. 21-25.
8. Каленська С. М. Ефективність застосування біогенних металів та біоактивних препаратів при вирощуванні сої [Електронний ресурс] / С. М. Каленська, К. Г. Лопатько, Н. В. Новицька // Наукові доповіді Наукового вісника НУБіП. 2011. - №5 (27). - Режим доступу : http://www.nbuv.gov.ua/e-journals/Nd/2011_5/11 ksm. pdf.

9. Каленська С. М., Шихман Н. В. Продуктивність сочевиці залежно від мінерального живлення та передпосівної обробки насіння в умовах Правобережного Лісостепу України [Електронний ресурс] / С. М. Каленська, Н. В. Шихман // Наукові доповіді НУБіП. - 2011. - №4 (26). Режим доступу : http://www.nbuv.gov.ua/ejournals/Nd/2011_4/ 11 ksm.pdf.

10. Мікробні препарати в землеробстві. Теорія i практика : монографія / [Волкогон В. В., Надкернична О. В., Ковалевська Т. М. та ін.] ; за ред. В. В. Волкогона. - К. : Аграрна наука, 2006. $312 \mathrm{c}$.

11. Shibairo Solomin I. Effect of Rhizobium inoculation and nitrogen fertilizer application on growth, nodulation and yield of two garden pea genotypes / Solomin I. Shibairo // Jour. Anim. and Plant Sci, 2012. - №15 (2). - P. 2147-2156.

12. Einheitliche Codierung derphänologischen Entwicklungsstadien mono- und dikotyler Pflanzen. Erweiterte BBCH-Skala: Allgemein / [Stauss R., Bleiholder H., Van Den Boom T., Buhr L., Hack H., Hess M., Klose R., Meier U. und Weber E.]. - CibaGeigy AG, Basel, 1994. - 58 s. 